\title{
Gene Mutations Associated with Temporomandibular Joint Disorders: A Systematic Review
}

\author{
Dhruvee Sangani1,2, Akiko Suzuki'2,3, Helena VonVille4, James E. Hixson'1, Junichi Iwata ${ }^{2,3,5 *}$ \\ ${ }^{1}$ Department of Epidemiology, Human Genetics \& Environmental Sciences, The University of Texas School of \\ Public Health, Houston, TX, USA \\ ${ }^{2}$ Department of Diagnostic \& Biomedical Sciences, The University of Texas Health Science Center at Houston \\ School of Dentistry, Houston, TX, USA \\ ${ }^{3}$ Center for Craniofacial Research, The University of Texas Health Science Center at Houston School of Dentistry, \\ Houston, TX, USA \\ ${ }^{4}$ The University of Texas School of Public Health Library, Houston, TX, USA \\ ${ }^{5}$ The University of Texas Graduate School of Biomedical Sciences at Houston, Houston, TX, USA \\ Email: Dhruvee.R.Sangani@uth.tmc.edu, Akiko.Suzuki@uth.tmc.edu, Helena.M.Vonville@uth.tmc.edu, \\ James.E.Hixson@uth.tmc.edu, ${ }^{*}$ Junichi.Iwata@uth.tmc.edu
}

Received 10 May 2015; accepted 31 May 2015; published 3 June 2015

Copyright @ 2015 by authors and OALib.

This work is licensed under the Creative Commons Attribution International License (CC BY).

http://creativecommons.org/licenses/by/4.0/

(c) (i) Open Access

\section{Abstract}

Background: The temporomandibular joint (TMJ) is a bilateral synovial joint between the mandible and the temporal bone of the skull. TMJ disorders (TMDs) are a set of complicated and poorly understood clinical conditions, in which TMDs are associated with a number of symptoms including pain and limited jaw movement. The increasing scientific evidence suggests that genetic factors play a significant role in the pathology of TMDs. However, the underlying mechanism of TMDs remains largely unknown. Objective: The study aimed to determine the associated genes to TMDs in humans and animals. Methods: The literature search was conducted through databases including Medline (Ovid), EMBASE (Ovid), and PubMed (NLM) by using scientific terms for TMDs and genetics in March 2015. Additional studies were identified by searching bibliographies of highly relevant articles and Scopus (Elsevier). Results: Our systematic analyses identified 31 articles through literature searches. A total of $\mathbf{1 1 2}$ genes were identified to be significantly and specifically associated with TMDs. Conclusion: Our systematic review provides a list of accurate genes associated with TMDs and suggests a genetic contribution to the pathology of TMDs.

\section{Keywords}

Temporomandibular Joint, Temporomandibular Joint Disorders, Systematic Review

${ }^{*}$ Corresponding author.

How to cite this paper: Sangani, D., Suzuki, A., VonVille, H., Hixson, J.E. and Iwata, J. (2015) Gene Mutations Associated with Temporomandibular Joint Disorders: A Systematic Review. Open Access Library Journal, 2: e1583.

http://dx.doi.org/10.4236/oalib.1101583 


\section{Subject Areas: Dentistry, Public Health}

\section{Introduction}

The temporomandibular joint (TMJ; aka the jaw joint) is a bilateral synovial joint between the mandible and the temporal bone. The TMJ consists of an articular disc located in the articular cavity, the glenoid fossa of the temporal bone and the mandibular condyle, and is filled with synovial fluid. The TMJ is unique because it consists of two joints in one bone, which is required to work simultaneously, and it acquires two major movements of the mandibular condyles: hinge and sliding, which is important for smoothly opening/closing mouth and chewing. TMJ disorders (TMDs) are a sub-classification of musculoskeletal disorders that result from stomatognathic system defects, and affect the function of masticatory muscles, the TMJ, and its associated structures [1].

TMDs are a set of complicated and poorly understood clinical conditions, which are associated with a number of symptoms including pain and limited jaw movement. The estimated prevalence of TMDs ranges from $5 \%$ to $60 \%$ worldwide [2]. TMDs occur as an individual disorder or associated with other syndromes, and TMJ pain is the second most common musculoskeletal pain after chronic low back pain [3] [4]. Since the symptoms of TMDs include pain, inflammation, and limited jaw movements, the etiology of TMDs may be complex. In addition, the susceptibility to TMDs may not be equal; for example, it is known that women are more susceptible than men. Severe and/or chronic cases of TMDs often occur with pain, but in mild cases, pain may be resolved over time. The possible influence factors of TMDs are mechanical and/or psychic stresses, hormones, genes, ethnicity, social status, and gender [5]. It has been postulated that women and adolescents have a higher risk for TMDs, compared to men [6] [7]. TMJ osteoarthritis (OA) is also diagnosed at the later stages of severe cases of TMDs [8]. The extent of causative genes of TMDs has been of prime interest [9]. The increasing scientific evidence suggests that genetic factors may play a significant role in the pathology of TMDs [10] [11]. However, the underlying mechanism of TMDs remains largely unknown. In this study, we performed a systematic review to identify genes associated with TMDs.

Currently, there are a few dental experts trained to precisely diagnose and treat this complex disorder. The treatment of TMDs has been very broad and general, including medications such as non-steroidal anti-inflammatory drugs (NSAIDs), muscle relaxants, physiotherapy, splints, biofeedback, and cognitive behavioral therapy. This study aims to provide precise information and highlight scientific literatures identifying genes associated with specific TMD conditions. Since not much research has been done on humans, animal studies have also been included in this systematic review. With knowledge of genetic studies, physicians and dentists can make diagnosis, tailor treatments, and predict susceptibility among people.

\section{Methods and Materials}

\subsection{Eligibility Criteria for Systemic Review}

The PRISMA (Preferred Reporting Items for Systematic reviews and Meta-Analyses) guideline and checklist was followed for this systematic review. Articles included in our systematic review met the following eligibility criteria: 1) described genes that are identified in TMDs; 2) were published as original articles (not as review articles, editorials, or comments); 3) were published in the English language; 4) were published between the years 2000 and 2015; and 5) specified TMD caused by gene mutations. Some articles were excluded from our systematic review because of one or more of the following reasons: a) gene mutations were not described in original articles; b) the type of TMDs (signs, symptoms, etc.) was not described or not diagnosed; c) the symptom was only pain, or the other symptoms and/or evaluations were not described; d) TMDs resulted from environmental factors; e) the studies had been done in other joints of the body; and f) others that include articles that failed to fit in any of the above criteria.

\subsection{Information Sources and Search}

The online databases that were searched included: Medline (Ovid), PubMed (National Library of Medicine), and EMBASE (Ovid). In addition, highly relevant citations were searched in Scopus (Elsevier) to determine if any unique studies were missed by the database searches. Bibliographies of highly relevant articles were also ex- 
amined. The Primary Excel Workbook for Systematic Reviews was used to track all search strategies and results, as described previously [12]. All search strategies are listed in full in Table S1 and Table S2. The search was limited to studies from 2000 through 2015 as genetic studies have become more technologically advanced in recent years, and very few genetic studies on TMDs were conducted before the year 2000.

\subsection{Study Selection and Data Collection}

RefWorks (Proquest) was used to store all citations found during the entire search process. The Primary Excel Workbook for Systematic Reviews (VonVille, Helena M. Primary Excel Workbook for Systematic Reviews, http://libguides.sph.uth.tmc.edu/excel_SR_workbook) was used to screen titles and abstracts of items found through database search. Titles and abstracts were screened by the first author (DS). The full text of articles not excluded was retrieved and reviewed by the first and second authors (DS, AS) with all data related to both screening and reviewing recorded in the Primary Excel Workbook. The data collected were displayed as a descriptive narrative. A codebook for data extraction from eligible articles was developed. The data elements that were extracted for the codebook included citation information, study level information (characteristics and results), and quality level information.

\section{Results and Discussions}

Nearly 900 unique articles were identified using the search strategies described above (see Figure 1 and Supplemental Information, Tables S1 and S2 for the database search strategies). Approximately $61 \%$ of the articles included were published after 2010. Interestingly, most of the articles included were published in 2014. Among the articles included for review $(n=31), 10$ studies were done on humans while 21 studies were conducted on animal models (Table 1 and Table 2). One study conducted research on both mouse and human subjects [13]. 18 out of 31 articles conducted research on mice while 1 article studied in porcine, 2 articles in rats, and 1 article in rabbits. The articles from 2000-2015 covered most of the research related to genes in TMDs. Eight studies were conducted in 2014 and 2 studies were conducted in 2015. The demographic characteristics among the human studies were very different. Among the human studies, different ethnic groups such as Koreans, Japanese, Brazilian, Finnish, and Turkish populations were studied (Table 1). Three articles did not mention the ethnicity of the population studied [14] [15] [16]. One study indicated that in the miscegenetic Brazilian population, the

2338 records identified from all sources

983 titles \& abstracts reviewed
1355 duplicates excluded

110 full text articles to be reviewed

2 articles not available

108 full text articles

31 publications included

873 Titles \& abstracts excluded

47 Not original research (i.e. review, comment, editorial, etc.)

416 Does not specify which genes were studied

239 Does not specify a TMD or focuses only on pain

4 Study of environmental or other causes of TMJ dysfunction

47 Treatment of TMJ dysfunction

36 Not the temporamandibular joint

84 Other

77 Full text articles excluded

1 Not original research (i.e. review, comment, editorial, etc.)

53 Does not specify which genes were studied

14 Does not specify a TMJ dysfunction/disease or focuses only on pain

1 Treatment of TMJ dysfunction

1 Not the temporamandibular joint

7 Other

Figure 1. Prisma flowchart for selection of articles. 
Table 1. Human studies.

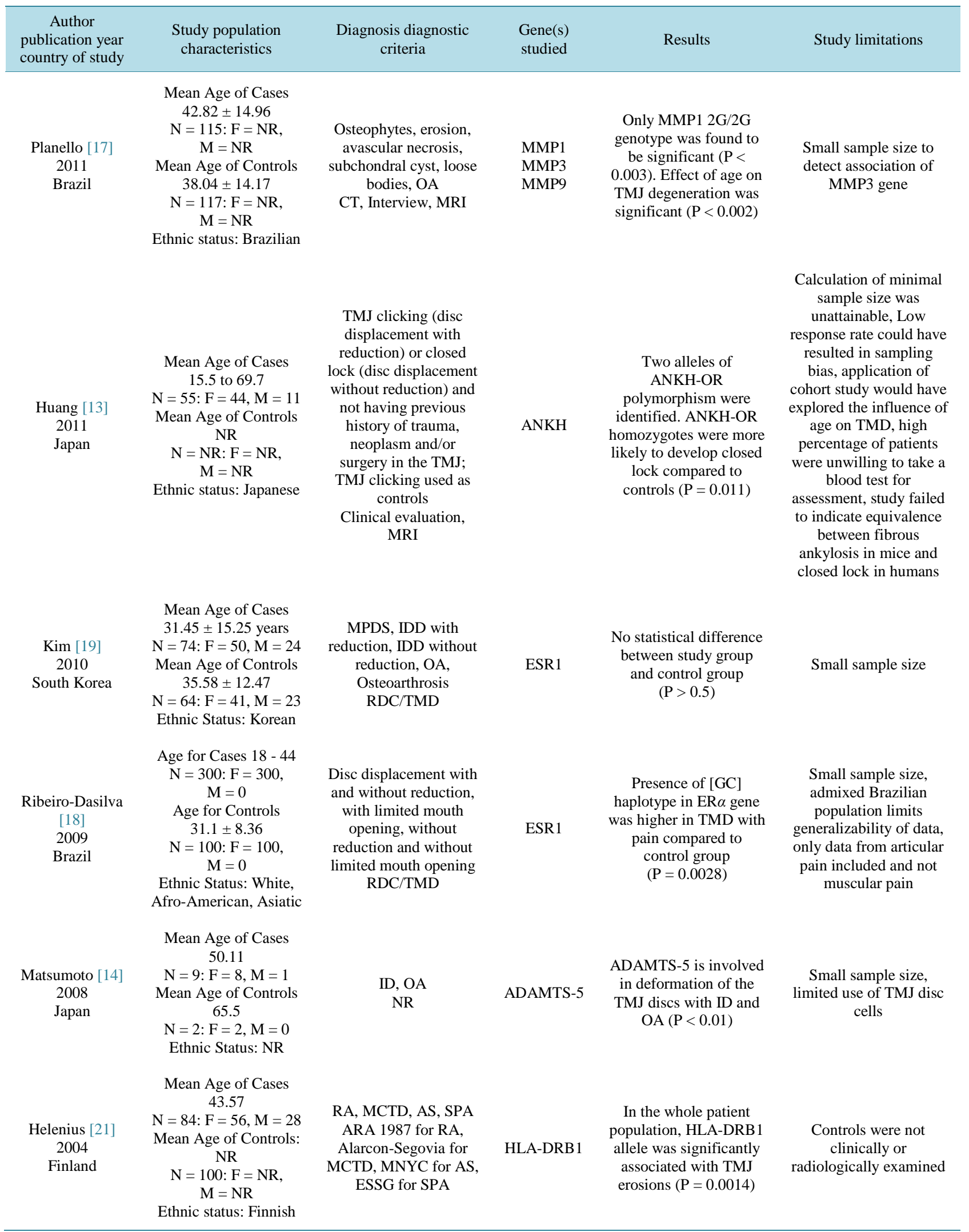




\section{Continued}

\begin{tabular}{|c|c|c|c|c|c|}
\hline $\begin{array}{l}\text { Li }[15] \\
2014 \\
\text { China }\end{array}$ & $\begin{array}{c}\text { Mean Age of Cases NR } \\
\mathrm{N}=3: \mathrm{F}=\mathrm{NR}, \mathrm{M}=\mathrm{NR} \\
\text { Mean Age of Controls } \\
\mathrm{NR} \\
\mathrm{N}=3: \mathrm{F}=\mathrm{NR}, \mathrm{M}=\mathrm{NR} \\
\text { Ethnic status: } \mathrm{NR}\end{array}$ & $\begin{array}{c}\text { Synovial } \\
\text { chondromatosis for } \\
\text { cases; Open Reduction } \\
\text { for controls } \\
\text { NR }\end{array}$ & FGF2 & $\begin{array}{l}\text { FGF2 was involved in } \\
\text { the pathogenesis of } \\
\text { synovial } \\
\text { chondromatosis } \\
(\mathrm{P}<0.01)\end{array}$ & NR \\
\hline $\begin{array}{l}\text { Yamaguchi [22] } \\
2015 \\
\text { Japan }\end{array}$ & $\begin{array}{c}\text { Mean Age of Cases } \\
\text { Japanese } 25.6 \\
\text { Koreans } 28.5 \\
\text { N of Japanese }=105: \\
\mathrm{F}=93, \mathrm{M}=12 \\
\mathrm{~N} \text { of Koreans }=41 \text { : } \\
\mathrm{F}=23, \mathrm{M}=18 \\
\text { Mean Age of Controls } \\
\text { Japanese } 25.6 \\
\text { Koreans } 28.5 \\
\mathrm{~N} \text { of Japanese }=193 \\
\mathrm{~F}=141, \mathrm{M}=53 \\
\mathrm{~N} \text { of Koreans }=181 \\
\mathrm{~F}=70, \mathrm{M}=111 \text { ) } \\
\text { Ethnic status: East } \\
\text { Asian }\end{array}$ & $\begin{array}{l}\text { Osteophytes, erosion, } \\
\text { flattening of TMJ bone } \\
\text { Interview, CT, MRI, } \\
\text { Panoramic Radiograph }\end{array}$ & $\begin{array}{c}\text { APOL3 } \\
\text { APP } \\
\text { CCDC81 } \\
\text { EXT2 } \\
\text { FRMD4A } \\
\text { FSTL4 } \\
\text { LOC100506 } \\
274 \\
\text { MRC2 } \\
\text { N4BP1 } \\
\text { OXR1 } \\
\text { PCSK5 } \\
\text { SLC24A4 } \\
\text { THRB } \\
\text { TPSAN9 } \\
\text { ULK4 } \\
\text { ZNF618 }\end{array}$ & $\begin{array}{l}\text { All the genes were } \\
\text { found to be significantly } \\
\text { associated. } \\
\text { TSPAN9 showed } \\
\text { strongest association } \\
\left(\mathrm{P}=8.1 \times 10^{-6}\right)\end{array}$ & $\begin{array}{l}\text { Small sample size, age } \\
\text { and gender differed } \\
\text { between Japanese and } \\
\text { Korean data sets }\end{array}$ \\
\hline $\begin{array}{l}\text { Etoz [20] } \\
2006 \\
\text { Turkey }\end{array}$ & $\begin{array}{c}\text { Mean Age of Cases } \\
21.1 \pm 12.1 \\
\mathrm{~N}=98 ; \mathrm{F}=75, \mathrm{M}=23 \\
\text { Mean Age of Controls } \\
22.9 \pm 10.1 \\
\mathrm{~N}=132: \mathrm{F}=104 \\
\mathrm{M}=28 \\
\text { Ethnic Status: Turkish }\end{array}$ & $\begin{array}{l}\text { Difficulty or pain while } \\
\text { opening mouth, locking } \\
\text { of jaw, pain, noises, } \\
\text { unusual bite, frequent } \\
\text { headache, MRI } \\
\text { findings-NR } \\
\text { Anamnestic } \\
\text { Questionnaire clinical } \\
\text { investigation, MRI }\end{array}$ & TNF & $\begin{array}{c}\text { TNF } \alpha \text {-308GApolymorp } \\
\text { hism is not associated } \\
\text { with TMD }\end{array}$ & $\begin{array}{l}\mathrm{NR} \\
\text { No radiological } \\
\text { diagnosis }\end{array}$ \\
\hline $\begin{array}{l}\text { Mutlu [16] } \\
2005 \\
\text { Turkey }\end{array}$ & $\begin{array}{c}\text { Mean Age of Cases: } \\
22.8 \pm 3.6 \text { years; } \\
\text { N = 93; F = 73, } \mathrm{M}=20 \\
\text { Mean Age of Controls } \\
21.10 \pm 3.7 \\
\mathrm{~N}=91: \mathrm{F}=61, \mathrm{M}=30 \\
\text { Ethnic Status: } \mathrm{NR}\end{array}$ & $\begin{array}{l}\text { Difficulty or pain while } \\
\text { opening mouth, locking } \\
\text { of jaw, pain, noises, } \\
\text { unusual bite, frequent } \\
\text { headache, MRI } \\
\text { findings-NR } \\
\text { Anamnestic } \\
\text { Questionnaire clinical } \\
\text { investigation, MRI }\end{array}$ & MAOA & $\begin{array}{l}\text { No evidence to support } \\
\text { the involvement of } \\
\text { MAOA gene in TMD }\end{array}$ & $\begin{array}{l}\text { NR } \\
\text { No radiological } \\
\text { diagnosis }\end{array}$ \\
\hline
\end{tabular}

NR: Not Reported; RA: Rheumatoid Arthritis; MCTD: Mixed Connective Tissue disease; AS: Ankylosing Spondylitis; SPA: Spondyloarthropathy; ARA: American Rheumatism Association; MNYC: Modified New York Criteria; ESSG: European Spondyloarthropathy Study Group; ID: Internal Derangement; OA: Osteoarthritis; MPDS: Myofacial Pain Dysfunction Syndrome; MRI: Magnetic Resonance Imaging; CT: Computed Tomography.

age was significantly associated with TMDs [17]. Two studies were carried out only in women to determine the association of the estrogen receptor alpha (ESR1) gene with TMDs. One study [18] indicated the contribution of ESR1 on TMDs whereas another study [19] suggested no association of ESR1 with TMD symptoms such as clicks, crepitus, and bone erosion. Females are more affected by TMJ pain and degeneration due to the effects of $\beta$-estradiol on the TMJ [18]. Three studies show no statistically significant changes in candidate TMD causative genes: MAOA (monoamine oxidase-A), ESR1 (estrogen receptor alpha), and TNF (tumor necrosis factor alpha) [16] [19] [20]. Several polymorphisms have been described in the promoter region of MMP genes, and these polymorphisms modify gene expression and function of the MMPs. MMP1 (matrix metalloproteinase 1) polymorphism, but not MMP3 and MMP9 polymorphisms, is associated with osteophyte and erosion of the mandibular condyle. In the Brazilian MMP1 2G/2G homozygous subjects, the probability of developing degeneration of the mandibular condyle is 2.47 times higher than that in the MMP1 $1 \mathrm{G} / 2 \mathrm{G}$ and $1 \mathrm{G} / 1 \mathrm{G}$ individuals [17]. ADAMTS5 (a disintegrin and metalloproteinase with thrombospondin motif 5) is involved in deformation of the articular disc associated with internal derangement and osteoarthritis in the TMJ [14]. Thus, proteinases contribute to degrade the articular disc and the surface of the mandibular condyle during the progression of TMDs. Homozygous polymorphism in ANKH (a human homolog of the murine progressive ankylosis gene, ank) more 
Table 2. Animal studies.

\begin{tabular}{|c|c|c|c|c|c|}
\hline $\begin{array}{c}\text { Author } \\
\text { publication year }\end{array}$ & $\begin{array}{l}\text { Animal } \\
\text { studies }\end{array}$ & $\begin{array}{l}\text { TMD condition } \\
\text { method of inducing } \\
\text { TMD }\end{array}$ & $\begin{array}{l}\text { Gene } \\
\text { studied }\end{array}$ & Results & $\begin{array}{c}\text { Study } \\
\text { limitations }\end{array}$ \\
\hline $\begin{array}{l}\text { Jing [25] } \\
2014\end{array}$ & Mice & $\begin{array}{l}\text { Mutant condylar } \\
\text { cartilage } \\
\text { Conditional } \\
\text { Osxknockout (cKO) } \\
\text { mice were generated by } \\
\text { crossing Osx-loxP mice } \\
\text { to Aggrecan-Cre mice. } \\
\text { Cre activity induced by } \\
\text { Tamoxifen injection }\end{array}$ & Osx & $\begin{array}{l}\text { Defect in coupling chondrogenesis } \\
\text { and osteogenesis in cKO mice, } \\
\text { calcified cartilage in hypertrophic } \\
\text { zone, few signs of endochondral bone } \\
\text { formation, disorganized } \\
\text { intramembranous bone }\end{array}$ & NR \\
\hline $\begin{array}{l}\text { Ishizuka [26] } \\
2014\end{array}$ & Mice & $\begin{array}{l}\text { OA-like changes } \\
\text { Mechanical stress }\end{array}$ & Samp8 & $\begin{array}{l}\text { Abnormal condylar organization, } \\
\text { condylar degeneration, decreased } \\
\text { chondroprogenitor cell proliferation } \\
\text { and increased cell death }\end{array}$ & NR \\
\hline $\begin{array}{c}\mathrm{Li}[27] \\
2014\end{array}$ & Mice & $\begin{array}{l}\text { Disc Disorder } \\
\text { Knock-in mouse line } \\
\text { with replacement of } \\
\text { mouse Shox2 by the } \\
\text { human SHOX coding } \\
\text { sequence }\end{array}$ & Shox2 & $\begin{array}{l}\text { Genetic association with congenital } \\
\text { articular disc degeneration, suggesting } \\
\text { that SHOX2 represents a susceptible } \\
\text { locus for OA of the TMJ }\end{array}$ & NR \\
\hline $\begin{array}{c}\text { Jiao [28] } \\
2014\end{array}$ & Mice & $\begin{array}{l}\text { Cartilage degradation } \\
\text { Green fluorescent } \\
\text { protein mice were } \\
\text { crossed with Cre mice }\end{array}$ & Tgfb1 & $\begin{array}{c}\text { Abnormalities in the subchondral } \\
\text { bone which induced cartilage } \\
\text { degradation }\end{array}$ & $\begin{array}{c}\text { Small } \\
\text { sample size }\end{array}$ \\
\hline $\begin{array}{c}\text { Inman [29] } \\
2013\end{array}$ & Mice & $\begin{array}{c}\text { Syngnathia, agenesis of } \\
\text { TMJ } \\
\text { Crossbreeding }\end{array}$ & Foxc1 & $\begin{array}{l}\text { Foxc1-/-mutant mice exhibit bilateral } \\
\text { fusion of the upper jaw zygomatic } \\
\text { complex to the dentary } \\
\text { bone (syngnathia) }\end{array}$ & NR \\
\hline $\begin{array}{c}\text { Ricks [30] } \\
2013\end{array}$ & Mice & $\begin{array}{c}\text { OA } \\
\text { Heterozygous mice } \\
(\mathrm{Dmm} /+) \text { of a } \mathrm{C}_{3} \mathrm{H} \text { strain } \\
\text { were crossed to produce } \\
\text { wildtype }(+/+) \text { and } \\
\text { Dmm } /+ \text { mice }\end{array}$ & Col2a1 & $\begin{array}{c}\text { TMJ in Dmm/+ mice displayed } \\
\text { premature articular cartilage and } \\
\text { greater defects in chondrocyte } \\
\text { arrangement, known biomarkers } \\
\text { of OA were significantly expressed } \\
(\mathrm{P}<0.01)\end{array}$ & NR \\
\hline $\begin{array}{l}\text { Yasuda [31] } \\
2012\end{array}$ & Mice & $\begin{array}{l}\text { Abnormal endochondral } \\
\text { ossification and Class } 3 \\
\text { dental malocclusion, } \\
\text { shortening of cranial } \\
\text { base } \\
\text { Knock-in mutation in } \\
\text { exon } 7 \text { of Fgfr3 gene }\end{array}$ & Fgfr3 & $\begin{array}{l}\text { Articular disc fused with temporal } \\
\text { bone, articular surface developed } \\
\text { fissures, defects in endochondral } \\
\text { ossification, abnormal glenoid fossa, } \\
\text { defective trabecular bone formation }\end{array}$ & NR \\
\hline $\begin{array}{c}\text { Purcell [32] } \\
2012\end{array}$ & Mice & $\begin{array}{c}\text { NR } \\
\text { Inactivation of genes } \\
\text { Spry1, Spry2 }\end{array}$ & $\begin{array}{l}\text { Spry1 } \\
\text { Spry2 }\end{array}$ & $\begin{array}{l}\text { Combined inactivation of Spry1 and } \\
\text { Spry2 genes leads to absence of } \\
\text { glenoid fossa and overgrowth of } \\
\text { lateral pterygoid and } \\
\text { temporalis muscles }\end{array}$ & NR \\
\hline $\begin{array}{c}\text { Huang [13] } \\
2011\end{array}$ & Mice & $\begin{array}{l}\text { Internal derangement } \\
\text { Commercially bred } \\
\text { ank/ank mutant mice } \\
\text { were purchased }\end{array}$ & Ank & $\begin{array}{l}\text { Fibrous ankylosis, narrower and/or } \\
\text { ankylosed superior and inferior } \\
\text { synovial cavities filled with fibrous } \\
\text { connective tissue throughout the } \\
\text { entire joint space }\end{array}$ & $\begin{array}{l}\text { Utilization of } \\
\text { 3-to-5 month } \\
\text { old mice in } \\
\text { this study } \\
\text { might be } \\
\text { responsible } \\
\text { for the } \\
\text { absence of } \\
\text { erosive } \\
\text { changes in } \\
\text { the TMJ. }\end{array}$ \\
\hline
\end{tabular}




\section{Continued}

\begin{tabular}{|c|c|c|c|c|c|}
\hline $\begin{array}{l}\text { Embree [33] } \\
2011\end{array}$ & Mice & $\begin{array}{c}\text { OA } \\
\text { Differential gene } \\
\text { expression analysis was } \\
\text { performed with RNA } \\
\text { extracted from 3-week } \\
\text { old WT and } b g n-/+; \\
\text { fmod-/- }\end{array}$ & $\begin{array}{l}\text { 4833416E15Rik } \\
\text { Aebp1, Ahsp } \\
\text { Angptl7, Arsk } \\
\text { Bace1, Bgn } \\
\text { Cartpt, Col2a1 } \\
\text { Col9a1, Col9a3 } \\
\text { Fmod, Hapln1 } \\
\text { LOC 344564 } \\
\text { Matn3, Mrpl30 } \\
\text { Pfn1, Ptprv } \\
\text { Rps19, Sfrp1 } \\
\text { Slc4a1, Tspan33 }\end{array}$ & $\begin{array}{l}\text { The microarray analysis discovered } \\
22 \text { genes differentially expressed in } \\
\text { bgn-/+; fmod-/- mouse model that } \\
\text { could be involved in disease initiation. } \\
5 \text { genes (Cartpt, Sfrp1, Arsk, Slc4a1, } \\
\text { Ptprv) changed in the mouse models } \\
\text { and are related to osteoclast f } \\
\text { unction/differentiation } \\
\text { and bone turnover }\end{array}$ & NR \\
\hline $\begin{array}{l}\text { Purcell [34] } \\
2009\end{array}$ & Mice & $\begin{array}{l}\text { Targeted disruption of } \\
\text { the Gli2 zinc finger } \\
\text { domain }\left(\mathrm{Gli} 2^{\text {zfd/zfd }}\right) \\
\text { Crossbreeding }\end{array}$ & Gli2 & $\begin{array}{c}\text { TMJ disk was missing, small condyle, } \\
\text { cellular organization of growth plate } \\
\text { was lost }\end{array}$ & NR \\
\hline $\begin{array}{c}\mathrm{Gu}[35] \\
2008\end{array}$ & Mice & $\begin{array}{l}\text { Inactivation of Shox2 } \\
\text { Shox2 conventional } \\
\text { knock out mice and mice } \\
\text { with floxed Shox2 allele } \\
\text { were generated. } \\
\text { Wnt1-Cre;Shox } 2^{\mathrm{F} / \mathrm{F}} \\
\text { obtained by mating }\end{array}$ & Shox2 & $\begin{array}{l}\text { Dysplasia of glenoid fossa, congenital } \\
\text { TMJ ankylosis }\end{array}$ & NR \\
\hline $\begin{array}{l}\text { Shibukawa [36] } \\
2006\end{array}$ & Mice & $\begin{array}{l}\text { Absence of articular disc } \\
\text { Absence of joint cavities } \\
\text { Crossbreeding and } \\
\text { induced mutation }\end{array}$ & Ihh & $\begin{array}{l}\text { Mandible development was defective, } \\
\text { condyle zonal architecture was } \\
\text { abnormal, complete absence of } \\
\text { functional disc and joint cavity }\end{array}$ & NR \\
\hline $\begin{array}{l}\text { Meng [37] } \\
2005\end{array}$ & Mice & $\begin{array}{l}\text { OA } \\
\text { Surgical lesion on discs, } \\
\text { gene expression profile }\end{array}$ & $\begin{array}{l}\text { Angpt12, Aqp3 } \\
\text { Baalc, Casr, } \\
\text { Cav, Chad, } \\
\text { Cldn11, Cls } \\
\text { Clu, Crabp2 } \\
\text { Csrp2, Dkk3 } \\
\text { Dpt, Egln3 } \\
\text { Eln, Gda, } \\
\text { Gda, Hig1 } \\
\text { Hspca, Htr2a } \\
\text { Igfbp5, Igfbp6 } \\
\text { Il11ra1, Lg11 } \\
\text { Lg11, Lib } \\
\text { Meox2, Mmp3 } \\
\text { Nb11, Nov } \\
\text { Nr1d1, Nt5 } \\
\text { Octnl, Plat } \\
\text { Prelp, Prrx2 } \\
\text { Pthlh, Scrg1 } \\
\text { Serpina1, Sfrp4 } \\
\text { Sod3, Spin2c } \\
\text { Spp2, Tgfbi } \\
\text { Thbs4, Tnfrsf11b } \\
\text { Tnmd }\end{array}$ & $\begin{array}{l}\text { Swelling, superficial fibrillation, early } \\
\text { osteoarthritic changes }\end{array}$ & NR \\
\hline $\begin{array}{l}\mathrm{Xu}[38] \\
2003\end{array}$ & Mice & $\begin{array}{l}\text { Cartilage Degeneration } \\
\text { Heterozygous cho/+ } \\
\text { mutant mice }\end{array}$ & cho & $\begin{array}{c}\text { At age } 6 \text { months OA-like changes } \\
\text { became more severe, including } \\
\text { flattening of the condylar head, loss of } \\
\text { proteoglycans, and a reduced } \\
\text { hypertrophic zone }\end{array}$ & NR \\
\hline $\begin{array}{c}\mathrm{Gu}[39] \\
2014\end{array}$ & Mice & $\begin{array}{l}\text { Apoptotic cells } \\
\text { Wnt1-Cre; Bmpr } 1 a^{F / F} \\
\text { embryos obtained by } \\
\text { crossing Wnt1-Cre; } \\
\text { Bmpr } 1 a^{F /+} \text { with } \\
\text { Bmpr } 1 a^{F / F} \text { line }\end{array}$ & Bmpr1a & $\begin{array}{l}\text { Agenesis Failed formation of } \\
\text { functional fibrocartilage layer, Failure } \\
\text { of disc separation from } \\
\text { hypoplastic condyle }\end{array}$ & NR \\
\hline
\end{tabular}




\section{Continued}

\begin{tabular}{|c|c|c|c|c|c|}
\hline $\begin{array}{c}\mathrm{Li}[40] \\
2014\end{array}$ & Mice & $\begin{array}{c}\text { Dysplasia } \\
\text { Cross of Wnt-Cre mice } \\
\text { with pMes-stopShox } 2 \\
\text { mice }\end{array}$ & Shox2 & $\begin{array}{l}\text { Increased number of apoptotic cells in } \\
\text { the glenoid fossa causing glenoid } \\
\text { fossa dysplasia, dysplasia of condyle }\end{array}$ & NR \\
\hline $\begin{array}{c}\text { Wang [41] } \\
2014\end{array}$ & Mice & $\begin{array}{c}\text { TMJ Cartilage } \\
\text { Degeneration } \\
\text { Crossbreeding to } \\
\text { generate } \\
\beta \text {-catenin }(\text { ex3 })^{\text {Col2ER }}, \\
\text { Tamoxifen administered }\end{array}$ & Ctnnb1 & $\begin{array}{l}\text { Significant reduction in TMJ joint } \\
\text { space, cartilage thickness was } \\
\text { significantly decreased, increase in } \\
\text { cartilage degrading enzymes, } \\
\text { OA-like phenotype }\end{array}$ & NR \\
\hline $\begin{array}{c}\text { Meng [42] } \\
2007\end{array}$ & Rats & $\begin{array}{l}\text { OA } \\
\text { Surgically, lesions } \\
\text { created in discs }\end{array}$ & $\begin{array}{l}\text { Aqp1 } \\
\text { Aqp3 }\end{array}$ & $\begin{array}{l}\text { High expression and different } \\
\text { localization of AQP3 in OA cartilage. } \\
\text { No significant difference between OA } \\
\text { and normal controls }\end{array}$ & NR \\
\hline $\begin{array}{c}\mathrm{Yu}[43] \\
2012\end{array}$ & Rats & $\begin{array}{l}\text { Condyle cartilage } \\
\text { Degeneration } \\
\text { Occlusal treatment } \\
\text { carried out to induce } \\
\text { degenerative changes in } \\
\text { the mandibular condylar } \\
\text { cartilage }\end{array}$ & $\begin{array}{l}\text { Igf1 } \\
\text { Gfr1 } \\
\text { Igfbp3 }\end{array}$ & $\begin{array}{c}\text { Obvious OA-like changes were } \\
\text { observed in } 2 \text { week female experi- } \\
\text { mental group than those in control } \\
\text { group }(\mathrm{P}<0.01) \text { and } 2 \text { week male } \\
\text { experimental group }(\mathrm{P}<0.05) \text {, } \\
\text { Expression of IGF1 in the } 2 \text { week } \\
\text { females was lower than males } \\
(\mathrm{P}<0.01) \text {, IGFR1 was significantly } \\
\text { lower in } 2 \text { week female }(\mathrm{P}<0.05) \text { but } \\
\text { increased in } 2 \text { week male } \\
\text { experimental group, IGFBP3 in all } \\
\text { female subgroups was significantly } \\
\text { lower than that in their male } \\
\text { counterparts }\end{array}$ & $\begin{array}{l}\text { Differences } \\
\text { in occlusion } \\
\text { between rats } \\
\text { and humans }\end{array}$ \\
\hline $\begin{array}{c}\text { Asakawa-Tanne } \\
\text { [44] } \\
2015\end{array}$ & Porcine & $\begin{array}{c}\text { Disc indentation } \\
\text { Porcine cranial heads } \\
\text { were subjected to cyclic } \\
\text { loading }\end{array}$ & $\begin{array}{l}\text { Cox2 } \\
\text { Il1b } \\
\text { Mmp1 } \\
\text { Mmp3 } \\
\text { Mmp9 }\end{array}$ & $\begin{array}{l}\text { Compromised lubrication in TMJ is } \\
\text { associated with altered frictional } \\
\text { properties and surface wear } \\
\text { of condylar cartilage }\end{array}$ & $\begin{array}{l}\text { Amount and } \\
\text { nature of } \\
\text { loading used } \\
\text { in the study } \\
\text { do not } \\
\text { represent the } \\
\text { actual TMJ } \\
\text { dynamics in } \\
\text { vivo }\end{array}$ \\
\hline $\begin{array}{c}\mathrm{Ge}[45] \\
2009\end{array}$ & Rabbit & $\begin{array}{l}\text { Cartilage destruction } \\
\text { Primary rabbit condylar } \\
\text { chondrocytes were } \\
\text { treated with IL- } \beta \text {, } \\
\text { purified WNT5A } \\
\text { protein, or both and } \\
\text { transfected with Wnt5a } \\
\text { expression vector }\end{array}$ & Wnt5a & $\begin{array}{l}\text { WNT5A is associated with cartilage } \\
\text { destruction by promoting expression } \\
\text { of MMP1, MMP3, MMP9, MMP13 }\end{array}$ & NR \\
\hline
\end{tabular}

NR: Not reported; OA: Osteoarthritis.

likely develops TMJ closed lock compared to controls [13]. The human leukocyte antigen (HLA) complex is a major histocompatibility complex (MHC) which is present on the surface of immune cells. Polymorphism in HLA-DRB1 (MHC class II, DR beta 1) allele is associated with erosion of the mandibular condyle [21]. These findings suggest that inflammation and autoimmune diseases may affect the progression of TMDs. Polymorphism in the fibroblast growth factor 2 (FGF2) gene is involved in the pathogenesis of TMJ synovial chondromatosis that is a rare proliferative disorder characterized by the formation of cartilaginous or osteocartilaginous nodules in synovium and articular cavities [15]. A recent genome-wide association study (GWAS) identified 22 independent loci showing association with degeneration of the mandibular condyle in East Asian populations. Among them, TSPAN9 (tetraspanin 9) polymorphism showed strongest association with TMD [22]. TSPAN9 mediates a signal transduction that plays a role in the regulation of cell development, activation, growth, and motility. Thus, some cell signaling pathways may be involved in the pathogenesis of TMDs. Although most of the studies have been done in small sample sizes, 28 out of 31 studies identified genes to be causal or associated 
with TMDs. This finding can lead us to believe that gene mutations are a causative factor for the incidence of TMDs.

In spite of extensive attempts, the molecular mechanism of TMDs is largely unknown because of the complex interaction of genes with other confounding factors like hormones, age, ethnicity, and environment. The presence of more than one symptom may be interdependent and act as a confounding factor [19]. Due to heterogeneity of symptoms, there are a lot of variations in diagnosis of TMDs worldwide. The appropriate treatments for TMD can only be initiated with a precise diagnosis. A number of imaging techniques including ultrasonography, computed tomography (CT), arthrography, and magnetic resonance imaging (MRI) have been adopted to confirm the diagnosis made by history taking and clinical examination. In 1992, The Research Diagnostic Criteria for Temporomandibular Disorders (RDC/TMD) was proposed as the basis for diagnosis of these complicated disorders [23]. In 2004, RDS/TMD has been replaced with Diagnostic Criteria for TMD (DC/TMD) because the validity of RDC/TMD was not sufficient enough in clinic [24]. Only 2 studies used the RDC/TMD diagnostic criteria, and none of the clinical studies have used the latest DC/TMD criteria yet.

This systematic review has much strength in identifying causative genes and their genetic interactions; however, it has a few limitations such as the year range of 2000-2015 and the English language. All the human studies had more number of females participating in the study. The participation of unequal numbers of gender might affect the validity of the results that women are more susceptible to TMDs. In addition, due to a broad classification and diagnostic criteria of TMDs, a potent detection bias cannot be ignored. Publication bias also can be the reason for limited literature being published. Future research with larger sample sizes will enable us to better understand genetic association with TMDs. Recent advances have introduced new techniques like GWAS that can help us discover genes associated with TMDs.

\section{Conclusion}

From a public health perspective, there is an urgent need to address TMDs and determine their causative factors. Despite different diagnostic criteria used, most of the included studies find associations between genes and TMDs. Future studies should incorporate objective diagnostic methods such as DC/TMD for TMD diagnosis to yield consistent results. Understanding the molecular mechanism is important to individualize treatment for TMDs in order to alleviate the overall burden of TMDs. Further studies to identify genes associated with TMDs will enable us to specifically diagnose TMDs and improve the quality of treatment. These findings will also help us understand why there is a gender disparity in TMDs and who may be more likely to suffer from TMDs.

\section{Acknowledgements}

This study was supported by start-up fund to J.I.

\section{Competing Interests}

The authors declare that they have no competing interests.

\section{Author's Contribution}

D. Sangani and H. VonVille performed literature search and drafted the article. A. Suzuki revised the manuscript for intellectual content. J. Hixson was involved in the discussion of the conception and results of the study. J. Iwata made substantial contributions to the conception and design of the paper, drafted and revised the article critically for important intellectual content and involved in the final approval of the version to be published. All authors read and approved the final manuscript.

\section{References}

[1] Tanaka, E., Detamore, M.S. and Mercuri, L.G. (2008) Degenerative Disorders of the Temporomandibular Joint: Etiology, Diagnosis, and Treatment. Journal of Dental Research, 87, 296-307. http://dx.doi.org/10.1177/154405910808700406

[2] Shaffer, S.M., Brismee, J.M., Sizer, P.S. and Courtney, C.A. (2014) Temporomandibular Disorders. Part 1: Anatomy and Examination/Diagnosis. The Journal of Manual \& Manipulative Therapy, 22, 2-12. http://dx.doi.org/10.1179/2042618613Y.0000000060 
[3] Mundt, T., Mack, F., Schwahn, C., Bernhardt, O., Kocher, T., et al. (2008) Association between Sociodemographic, Behavioral, and Medical Conditions and Signs of Temporomandibular Disorders across Gender: Results of the Study of Health in Pomerania (SHIP-0). The International Journal of Prosthodontics, 21, 141-148.

[4] Leboeuf-Yde, C., Nielsen, J., Kyvik, K.O., Fejer, R. and Hartvigsen, J. (2009) Pain in the Lumbar, Thoracic or Cervical Regions: Do Age and Gender Matter? A Population-Based Study of 34,902 Danish Twins 20-71 Years of Age. BMC Musculoskeletal Disorders, 10, 39. http://dx.doi.org/10.1186/1471-2474-10-39

[5] Magalhaes, B.G., de-Sousa, S.T., de Mello, V.V., da-Silva-Barbosa, A.C., de-Assis-Morais, M.P., et al. (2014) Risk Factors for Temporomandibular Disorder: Binary Logistic Regression Analysis. Medicina Oral Patologia Oral y Cirugia Bucal, 19, e232-e236. http://dx.doi.org/10.4317/medoral.19434

[6] Dworkin, S.F., Huggins, K.H., LeResche, L., Von Korff, M., Howard, J., et al. (1990) Epidemiology of Signs and Symptoms in Temporomandibular Disorders: Clinical Signs in Cases and Controls. The Journal of the American Dental Association, 120, 273-281. http://dx.doi.org/10.14219/jada.archive.1990.0043

[7] Bagis, B., Ayaz, E.A., Turgut, S., Durkan, R. and Ozcan, M. (2012) Gender Difference in Prevalence of Signs and Symptoms of Temporomandibular Joint Disorders: A Retrospective Study on 243 Consecutive Patients. International Journal of Medical Sciences, 9, 539-544. http://dx.doi.org/10.7150/ijms.4474

[8] Wadhwa, S., Embree, M., Ameye, L. and Young, M.F. (2005) Mice Deficient in Biglycan and Fibromodulin as A Model for Temporomandibular Joint Osteoarthritis. Cells Tissues Organs, 181, 136-143. http://dx.doi.org/10.1159/000091375

[9] Oakley, M. and Vieira, A.R. (2008) The Many Faces of the Genetics Contribution to Temporomandibular Joint Disorder. Orthodontics \& Craniofacial Research, 11, 125-135. http://dx.doi.org/10.1111/j.1601-6343.2008.00426.x

[10] Fillingim, R.B., Wallace, M.R., Herbstman, D.M., Ribeiro-Dasilva, M. and Staud, R. (2008) Genetic Contributions to Pain: A Review Of Findings in Humans. Oral Diseases, 14, 673-682. http://dx.doi.org/10.1111/j.1601-0825.2008.01458.x

[11] Smith, S.B., Mir, E., Bair, E., Slade, G.D., Dubner, R., et al. (2013) Genetic Variants Associated with Development of TMD and Its Intermediate Phenotypes: The Genetic Architecture of TMD in the OPPERA Prospective Cohort Study. Journal of Pain, 14, T91-T101.e3. http://dx.doi.org/10.1016/j.jpain.2013.09.004

[12] Davlin, S.L. and VonVille, H.M. (2012) Canine Rabies Vaccination and Domestic Dog Population Characteristics in the Developing World: A Systematic Review. Vaccine, 30, 3492-3502. http://dx.doi.org/10.1016/j.vaccine.2012.03.069

[13] Huang, B., Takahashi, K., Sakata, T., Kiso, H., Sugai, M., et al. (2011) Increased Risk of Temporomandibular Joint Closed Lock: A Case-Control Study of ANKH Polymorphisms. PLoS ONE, 6, e25503. http://dx.doi.org/10.1371/journal.pone.0025503

[14] Matsumoto, T., Tojyo, I., Kiga, N., Hiraishi, Y. and Fujita, S. (2008) Expression of ADAMTS-5 in Deformed Human Temporomandibular Joint Discs. Histology and Histopathology, 23, 1485-1493.

[15] Li, Y.J., Cai, H.X., Fang, W., Meng, Q.G., Li, J., et al. (2014) Fibroblast Growth Factor 2 Involved in the Pathogenesis of Synovial Chondromatosis of Temporomandibular Joint. Journal of Oral Pathology \& Medicine, 43, 388-394. http://dx.doi.org/10.1111/jop.12146

[16] Mutlu, N., Erdal, M.E., Herken, H., Ozkaya, M., Erdal, N., Oz, G., et al. (2005) Monoamine Oxidase-A Gene Promoter Polymorphism in Temporomandibular Joint Pain and Dysfunction. Pain Clinics, 17, 39-44.

[17] Planello, A.C., Campos, M.I., Meloto, C.B., Secolin, R., Rizatti-Barbosa, C.M., et al. (2011) Association of Matrix Metalloproteinase Gene Polymorphism with Temporomandibular Joint Degeneration. European Journal of Oral Sciences, 119, 1-6. http://dx.doi.org/10.1111/j.1600-0722.2010.00803.x

[18] Ribeiro-Dasilva, M.C., Peres Line, S.R., dos Santos, M.C.L.G., Arthuri, M.T., Hou, W., Fillingim, R.B., et al. (2009) Estrogen Receptor- $\alpha$ Polymorphisms and Predisposition to TMJ Disorder. Journal of Pain, 10, 527-533. http://dx.doi.org/10.1016/j.jpain.2008.11.012

[19] Kim, B.S., Kim, Y.K., Yun, P.Y., Lee, E. and Bae, J. (2010) The Effects of Estrogen Receptor $\alpha$ Polymorphism on the Prevalence of Symptomatic Temporomandibular Disorders. Journal of Oral and Maxillofacial Surgery, 68, 2975-2979. http://dx.doi.org/10.1016/j.joms.2010.02.023

[20] Etoz, O.A., Erdal, M.E., Herken, H., Bayazit, Y.A. and Mutlu, M.N. (2006) Lack of Association between the 308GA Polymorphism of the Tumor Necrosis Factor $\alpha$ Gene and Temporomandibular Dysfunction. Pain Clinics, 18, 175-180.

[21] Helenius, L.M., Hallikainen, D., Helenius, I., Meurman, J.H., Koskimies, S., et al. (2004) HLA-DRB1* Alleles and Temporomandibular Joint Erosion in Patients with Various Rheumatic Diseases. Scandinavian Journal of Rheumatology, 33, 24-29. http://dx.doi.org/10.1080/03009740310004603

[22] Yamaguchi, T., Nakaoka, H., Yamamoto, K., Fujikawa, T., Kim, Y.I., et al. (2014) Genome-Wide Association Study of Degenerative Bony Changes of the Temporomandibular Joint. Oral Diseases, 20, 409-415. http://dx.doi.org/10.1111/odi.12141 
[23] Ahmad, M., Hollender, L., Anderson, Q., Kartha, K., Ohrbach, R., et al. (2009) Research Diagnostic Criteria for Temporomandibular Disorders (RDC/TMD): Development of Image Analysis Criteria and Examiner Reliability for Image Analysis. Oral Surgery, Oral Medicine, Oral Pathology, Oral Radiology, and Endodontology, 107, 844-860. http://dx.doi.org/10.1016/j.tripleo.2009.02.023

[24] Schiffman, E., Ohrbach, R., Truelove, E., Look, J., Anderson, G., et al. (2014) Diagnostic Criteria for Temporomandibular Disorders (DC/TMD) for Clinical and Research Applications: Recommendations of the International RDC/TMD Consortium Network* and Orofacial Pain Special Interest Groupdagger. Journal of Oral \& Facial Pain and Headache, 28, 6-27. http://dx.doi.org/10.11607/jop.1151

[25] Jing, J., Hinton, R.J., Jing, Y., Liu, Y., Zhou, X. and Feng, J.Q. (2014) Osterix Couples Chondrogenesis and Osteogenesis in Post-Natal Condylar Growth. Journal of Dental Research, 93, 1014-1021. http://dx.doi.org/10.1177/0022034514549379

[26] Ishizuka, Y., Shibukawa, Y., Nagayama, M., Decker, R., Kinumatsu, T., Saito, A., et al. (2014) TMJ Degeneration in SAMP8 Mice Is Accompanied by Deranged Ihh Signaling. Journal of Dental Research, 93, 281-287. http://dx.doi.org/10.1177/0022034513519649

[27] Li, X.H., Liang, W.N., Ye, H.Z., Weng, X.P., Liu, F.Y. and Liu, X.X. (2014) Overexpression of Shox2 Leads to Congenital Dysplasia of the Temporomandibular Joint in Mice. International Journal of Molecular Sciences, 15, 1313513150. http://dx.doi.org/10.3390/ijms150813135

[28] Jiao, K., Zhang, M., Niu, L., Yu, S., Zhen, G., Xian, L., et al. (2014) Overexpressed TGF- $\beta$ in Subchondral Bone Leads to Mandibular Condyle Degradation. Journal of Dental Research, 93, 140-147. http://dx.doi.org/10.1177/0022034513513034

[29] Inman, K.E., Purcell, P., Kume, T. and Trainor, P.A. (2013) Interaction between Foxc1 and Fgf8 during Mammalian Jaw Patterning and in the Pathogenesis of Syngnathia. PLoS Genetics, 9, e1003949. http://dx.doi.org/10.1371/journal.pgen.1003949

[30] Ricks, M.L., Farrell, J.T., Falk, D.J., Holt, D.W., Rees, M., Carr, J., et al. (2013) Osteoarthritis in Temporomandibular Joint of Col2a1 Mutant Mice. Archives of Oral Biology, 58, 1092-1099. http://dx.doi.org/10.1016/j.archoralbio.2013.02.008

[31] Yasuda, T., Nah, H.D., Laurita, J., Kinumatsu, T., Shibukawa, Y., Shibutani, T., et al. (2012) Muenke Syndrome Mutation, FgfR3 ${ }^{P 244 R}$, Causes TMJ Defects. Journal of Dental Research, 91, 683-689. http://dx.doi.org/10.1177/0022034512449170

[32] Purcell, P., Jheon, A., Vivero, M.P., Rahimi, H., Joo, A. and Klein, O.D. (2012) Spry1 and Spry2 Are Essential for Development of the Temporomandibular Joint. Journal of Dental Research, 91, 387-393. http://dx.doi.org/10.1177/0022034512438401

[33] Embree, M., Ono, M., Kilts, T., Walker, D., Langguth, J., Mao, J., et al. (2011) Role of Subchondral Bone during Early-Stage Experimental TMJ Osteoarthritis. Journal of Dental Research, 90, 1331-1338. http://dx.doi.org/10.1177/0022034511421930

[34] Purcell, P., Joo, B.W., Hu, J.K., Tran, P.V., Calicchio, M.L., O’Connell, D.J., et al. (2009) Temporomandibular Joint Formation Requires Two Distinct Hedgehog-Dependent Steps. Proceedings of the National Academy of Sciences of the United States of America, 106, 18297-18302. http://dx.doi.org/10.1073/pnas.0908836106

[35] Gu, S.P., Wei, N., Yu, L., Fei, J. and Chen, Y.P. (2008) Shox2-Deficiency Leads to Dysplasia and Ankylosis of the Temporomandibular Joint in Mice. Mechanisms of Development, 125, 729-742. http://dx.doi.org/10.1016/j.mod.2008.04.003

[36] Shibukawa, Y., Young, B., Wu, C.S., Yamada, S., Long, F.X., Pacifici, M., et al. (2007) Temporomandibular Joint Formation and Condyle Growth Require Indian Hedgehog Signaling. Developmental Dynamics, 236, 426-434. http://dx.doi.org/10.1002/dvdy.21036

[37] Meng, J.H., Ma, X.C., Ma, D.L. and Xu, C.M. (2005) Microarray Analysis of Differential Gene Expression in Temporomandibular Joint Condylar Cartilage after Experimentally Induced Osteoarthritis. Osteoarthritis \& Cartilage, 13, 11151125. http://dx.doi.org/10.1016/j.joca.2005.03.010

[38] Xu L, Flahiff, C.M., Waldman, B.A., Wu, D., Olsen, B.R., Setton, L.A., et al. (2003) Osteoarthritis-Like Changes and Decreased Mechanical Function of Articular Cartilage in the Joints of Mice with the Chondrodysplasia Gene (Cho). Arthritis \& Rheumatism, 48, 2509-2518. http://dx.doi.org/10.1002/art.11233

[39] Gu, S.P., Wu, W.J., Liu, C., Yang, L., Sun, C., Ye, W.D., et al. (2014) BMPRIA Mediated Signaling Is Essential for Temporomandibular Joint Development in Mice. PLoS ONE, 9, e101000. http://dx.doi.org/10.1371/journal.pone.0101000

[40] Li, X.H., Liu, H.B., Gu, S.P., Liu, C., Sun, C., Zheng, Y.Q., et al. (2014) Replacing Shox2 with Human SHOX Leads to Congenital Disc Degeneration of the Temporomandibular Joint in Mice. Cell \& Tissue Research, 355, 345-354. 
http://dx.doi.org/10.1007/s00441-013-1743-2

[41] Wang, M., Li, S., Xie, W., Shen, J., Im, H.J., Holz, J.D., et al. (2014) Activation of $\beta$-Catenin Signalling Leads to Temporomandibular Joint Defects. European Cells \& Materials, 28, 223-235.

[42] Meng, J.H., Ma, X.C., Li, Z.M. and Wu, D.C. (2007) Aquaporin-1 and Aquaporin-3 Expressions in the Temporomandibular joint Condylar Cartilage after an Experimentally Induced Osteoarthritis. Chinese Medical Journal, 120, 21912194.

[43] Yu, S., Sun, L., Liu, L., Jiao, K. and Wang, M. (2012) Differential Expression of IGF1, IGFR1 and IGFBP3 in Mandibular Condylar Cartilage between Male and Female Rats Applied with Malocclusion. Journal of Oral Rehabilitation, 39, 727-736.

[44] Asakawa-Tanne, Y., Su, S., Kunimatsu, R., Hirose, N., Mitsuyoshi, T., Okamoto, Y., et al. (2015) Effects of Enzymatic Degradation after Loading in Temporomandibular Joint. Journal of Dental Research, 94, 337-343. http://dx.doi.org/10.1177/0022034514560588

[45] Ge, X.P., Ma, X.C., Meng, J.H., Zhang, C.G., Ma, K.T. and Zhou, C.Y. (2009) Role of Wnt-5A in Interleukin-1 $\beta$-Induced Matrix Metalloproteinase Expression in Rabbit Temporomandibular Joint Condylar Chondrocytes. Arthritis \& Rheumatism, 60, 2714-2722. http://dx.doi.org/10.1002/art.24779

\section{Abbreviations}

DC/TMD: Diagnostic Criteria for TMD

ESR1: Estrogen Receptor Alpha

GWAS: Genome-Wide Association Study

MAOA: Monoamine Oxidase-A

NSAIDs: Non-Steroidal Anti-Inflammatory Drugs

PRISMA: Preferred Reporting Items for Systematic Reviews and Meta-Analyses

RDC/TMD: Research Diagnostic Criteria for Temporomandibular Disorders

TMDs: Temporomandibular Joint Disorders

TMJ: Temporomandibular Joint

TNF: Tumor Necrosis Factor Alpha 


\section{Supplemental Information}

Table S1. Summary of databases searched.

\begin{tabular}{|c|c|c|c|c|c|}
\hline Table & $\begin{array}{l}\text { Vendor/ } \\
\text { Interface }\end{array}$ & Database & Date searched & Database update & Searcher(s) \\
\hline $1 \mathrm{a}$ & Ovid & Medline $^{\circledR}$ & $2 / 25 / 2015$ & $\begin{array}{l}1996 \text { to February Week } 32015 ; \\
\text { In-Process \& Other Non-Indexed } \\
\text { Citations February 24, } 2015\end{array}$ & $\begin{array}{c}\text { Helena M. } \\
\text { VonVille; } \\
\text { Dhruvee Sangani }\end{array}$ \\
\hline $1 b$ & $\begin{array}{l}\text { National Library } \\
\text { of Medicine }\end{array}$ & PubMed & $1 / 28 / 2015$ & $1 / 28 / 2015$ & $\begin{array}{l}\text { Helena M. } \\
\text { VonVille; Dhruvee } \\
\text { Sangani }\end{array}$ \\
\hline 1c & Ovid & Embase $^{\circledR}$ & $1 / 29 / 2015$ & 1974 to 2015 January 27 & $\begin{array}{c}\text { Helena M. } \\
\text { VonVille }\end{array}$ \\
\hline
\end{tabular}

\section{Table S2. Codebook.}

ID

Variable name (coding instructions)

\section{Values, text codes}

Citation information

C 1

C 2

C 3

C 4

C 5

C 7

C8

Ref ID

(Numerical) (ranges from 1-1010)

\section{Name of coder}

Publication date

Author

Type of citation

Secondary cite(s)-

Ref ID \#, publication date, author, journal

Number of studies reported in this citation

Note: default $=1$

Study level information (characteristics and results)

Study design

S 3

S 4

Sponsor (check one)

S 5

Type of TMD disorder alphabetize list

Species

Gene(s) studied

7

Gene(s) studied

Laboratory experiment/translational research

Other (specify):

Study location-state/province, city, \& country:

Industry sponsored

Cannot be ascertained

Other (specify)

Agenesis

Ankylosis

Disc derangement

Dysplasia

Internal derangement

Osteoarthritis

Syngnathia

Other (specify)

Humans

Animals a) Mice; b) Rabbit; c) Rat; d) Sheep Other (Specify) 


\section{Continued}

Q 1 Did the study describe the method of embryo collection and genotyping?

Did the study describe eligibility criteria and methods used to select participants?

Q 3 Were the statistical analysis reported? 2-No

Did the study describe the trial design?

Q 5 Did the study explain sample size calculations

What were the key limitations according to the authors?

Q9 Did the authors discuss the external validity?

Did the study describe eligibility criteria and methods used to select participants?

Q 12 Was the association of genes with TMJ Disorders clearly described?

Did the study describe any measures to 